\title{
Nazugum, a new 4000 year old rockshelter site in the Ili Alatau, Tien Shan
}

\author{
Abay Namen ${ }^{1,2}$, Aristeidis Varis ${ }^{1,3}$, Susanne Lindauer ${ }^{4}$, Ronny Friedrich ${ }^{4}$, \\ Zhaken Taimagambetov ${ }^{2,5}$, Radu Iovita ${ }^{1,6}$
}

\footnotetext{
${ }^{1}$ Department of Early Prehistory and Quaternary Ecology, University of Tübingen, Tübingen 72070, Germany

${ }^{2}$ Department of Archaeology, Ethnology and Museology, Faculty of History, Archaeology and Ethnology, Al Farabi Kazakh National University, Almaty 050040, Kazakhstan

${ }^{3}$ Institute of Archaeological Sciences, University of Tübingen, Tübingen 72070, Germany

${ }^{4}$ Curt-Engelhorn-Zentrum Archäometrie gGmbH, 68159 Mannheim, Germany

${ }^{5}$ National Museum of the Republic of Kazakhstan, Nur-Sultan 010000, Kazakhstan

${ }^{6}$ Center for the Study of Human Origins, Department of Anthropology, New York University, New York 10003, USA
}

\section{Abstract}

The PALAEOSILKROAD project has been conducting field surveys in Kazakhstan to explore the regional Palaeolithic record by targeting primarily caves and rockshelters. However, the survey also discovered numerous sites that were occupied during the Holocene. In this paper, we present our preliminary findings from the Nazugum rockshelter, a new archaeological site located in south-eastern Kazakhstan (Almaty region). The stratigraphic sequence demonstrates the transition from fluvial channel deposits without artifacts to aeolian loess deposits with lithics, charcoal remnants, and fragments of animal bones. The lithics recovered from the sediment wall are dominated by bladelet technology, characteristic for Holocene assemblages. Radiocarbon date from adjacent charcoal samples yielded a calibrated age (2-sigma) of 2470$2288 \mathrm{cal}$ BC attributing the human occupation to the transitional period of late Eneolithic and early Bronze Age. Our study provides new data for the use of rockshelters in Kazakhstan during the late Holocene and lays the groundwork for future salvage work in Nazugum rockshelter due to the active erosion of the archaeological record.

Keywords: C14; loess; Eneolithic; Central Asia; lithics; Nazugum

Corresponding author: Abay Namen at Hölderlinstraße 12, 72070 Tübingen, Germany (abay.namen@uni-tuebingen.de) 


\section{Introduction}

The Holocene archaeology of Kazakhstan is well represented and has been a major research focus over the decades. The majority of Holocene sites chronologically fall into the Eneolithic, Bronze, and Iron Age periods and are typically open-air settlements or burial sites that can visually be located by reconnaissance works or aerial survey. For instance, the discovery of the Eneolithic site of Botai in northern Kazakhstan became an increasingly valuable site helping to address questions on early animal domestication problems in Eurasian Steppes. In addition to the large horse remains at Botai, organic residue analysis on ceramic sherds show earliest evidence of horse harnessing and milking (Outram et al., 2009). The excavations of Bronze and Iron Age settlements and burials also contribute to the study of technological developments and formation of pastoral societies (Frachetti, 2012).

Between the $4^{\text {th }}$ and $2^{\text {nd }}$ millennia BP the first Eneolithic and Early Bronze Age artifacts emerge. In central and eastern Kazakhstan, archaeologists revealed over 100 open-air settlements with evidence of metal smelting, such as the localities of Zhezqazgan and Zyryanovsk (Zaibert, 1993). In northern Kazakhstan, the Eneolithic settlements of Botai and Krasnyi Yar dominate the archaeological landscape (Zaibert, 1993). However, despite the emergence of sophisticated technology and use of metals during the Bronze age and the Eneolithic, prehistoric people continued knapping stone tools. Moreover, even though early Holocene open-air sites are particularly common, cultural remains from cave and rockshelter contexts attributed to this period are relatively rare. Most cave sites with Holocene sediments are dated to the Neolithic (e.g., Qaraungir-1 (Taimagambetov and Nokhrina, 1998) and Yntaly-3 (G. Iskakov 2018, pers. comm.). Later Bronze Age and Medieval periods have also been recently documented from cave contexts at Tuttybulaq (Baytanaev et al., 2018) in southern Kazakhstan, although the site is an example of a special use, for iron smelting.

Our recent work in Kazakhstan incorporated systematic survey of cave sites and resulted in the recording of new sites with Holocene remains (Fig. 1). In this paper, we present radiocarbon date from one of these sites, Nazugum rockshelter, as well as describe the geological context and archaeological assemblage. 


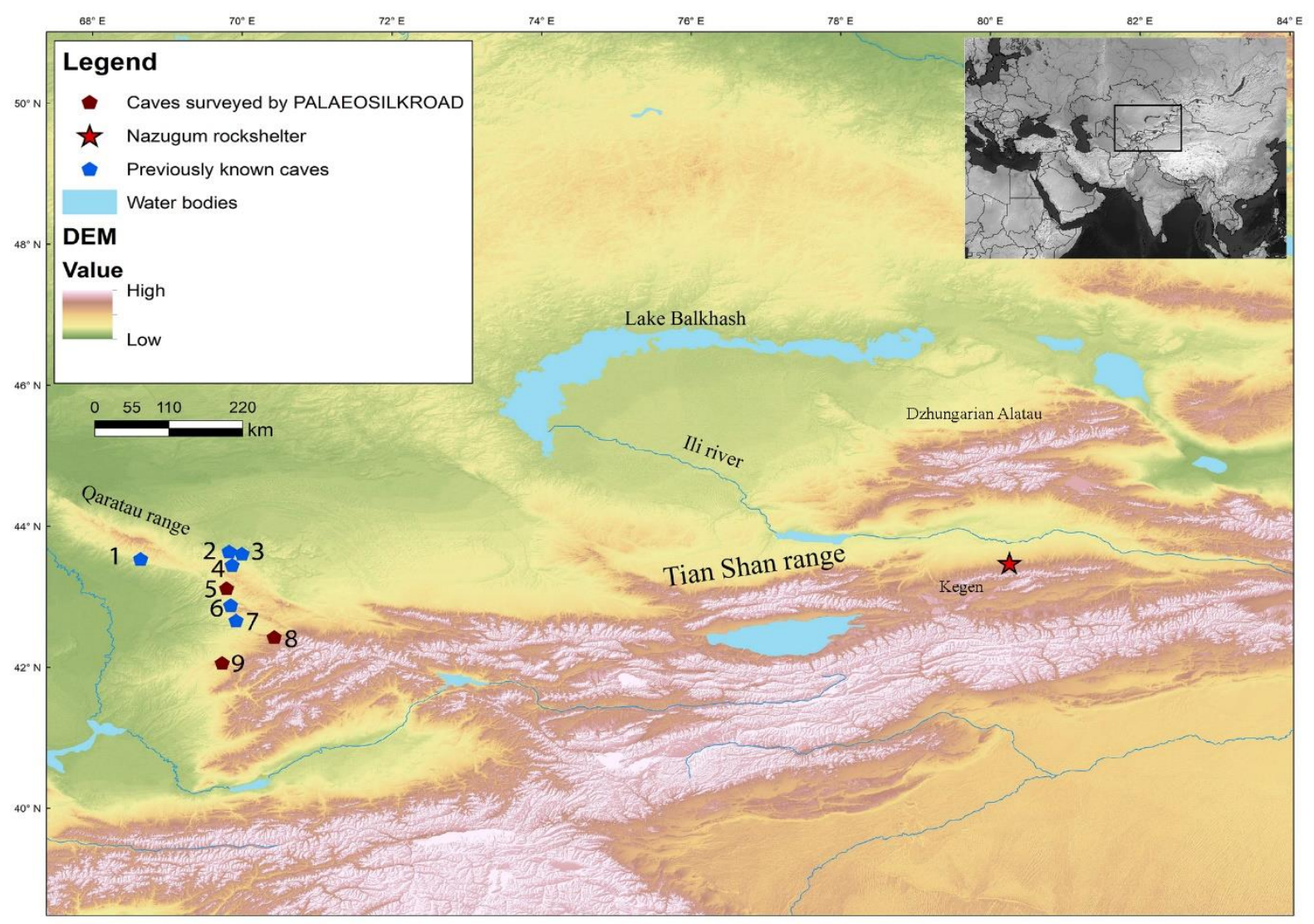

Figure 1. Illustration of known Holocene cave-sites in southern Kazakhstan shown in relation to regional topography. 1) Hantagi-1 and Ushozen, 2) Mayatas, 3) Yntaly-3, 4) Aqtogai 1, 5) Jetiotau, 6) Tuttybulaq-1-2, 7) Qaraungir-1, 8) Taldybulaq-1, 9) Temir-2

\section{Nazugum rockshelter}

Nazugum is a rockshelter located at the northern foothills of the Ili Alatau Mountain range, northern Tian Shan, Kazakhstan (Fig. 1). The site was located during the cave prospection mission of the PALAEOSILKROAD project in 2019 (Namen et al., 2020a; Cuthbertson et al., 2021). It was named after an Uyghur girl who fled China and sought a refuge in this rockshelter from the Manchurian persecution in the $19^{\text {th }}$ century. Currently it is used as a pilgrimage site to pay respect to the memory of Nazugum by the Uyghur minorities of the region.

During our survey we observed that the surrounding landscape of the Nazugum rockshelter is rich in previously undocumented Bronze and Iron Age sites, especially at the locality of Kegen. These sites are mostly burial mounds. Further north of Nazugum, in the Dzhungarian Alatau, the presence of one of the earliest Bronze Age pastoral settlements demonstrates the importance of the region during the later prehistory (Frachetti and Mar'yashev, 2007; Frachetti et al., 2010). Additionally, a complex of Bronze Age petroglyphs located along the Ili River dominate the archaeological landscape (Zheleznyakov et al., 2020). Earlier sites of Eneolithic, and Early Bronze Age chronology are not well documented in the region, calling for more systematic survey work.

In terms of geology, Nazugum is a pseudokarstic rockshelter formed by the eroding action of the Ketmen river curving local volcanic rocks that shaped the intensely dissected volcanic rock highlands. The biggest part of the rockshelter does not contain any sediment, but sediment columns that reach up to the ceiling can be found in the front area, below the dripline (Fig. 2). The formation of these isolated columns necessitates a continuous and spatially extensive 
accumulation of sediment, implying that the rockshelter was once completely covered with sediment. The stratigraphic sequence records two broad stratigraphic units (Fig. 2). The lower unit (Unit 1) consists of imbricated gravel layers interlaminated with clays and fine sands demonstrating a period of fluvial deposition and channel widening. The upper unit (Unit 2) is dominated by approximately 2 meters of massive loess sediments indicating wind-blown sedimentation in the cavity. Progressive downcutting of the stream's bed led to the modern river level, about 5 meters below the cave floor. Morphological features like sediment arches indicate the presence of water channels that actively erode the remaining sediment and probably eroded most of the sediment in the past (Iovita et al., 2020).

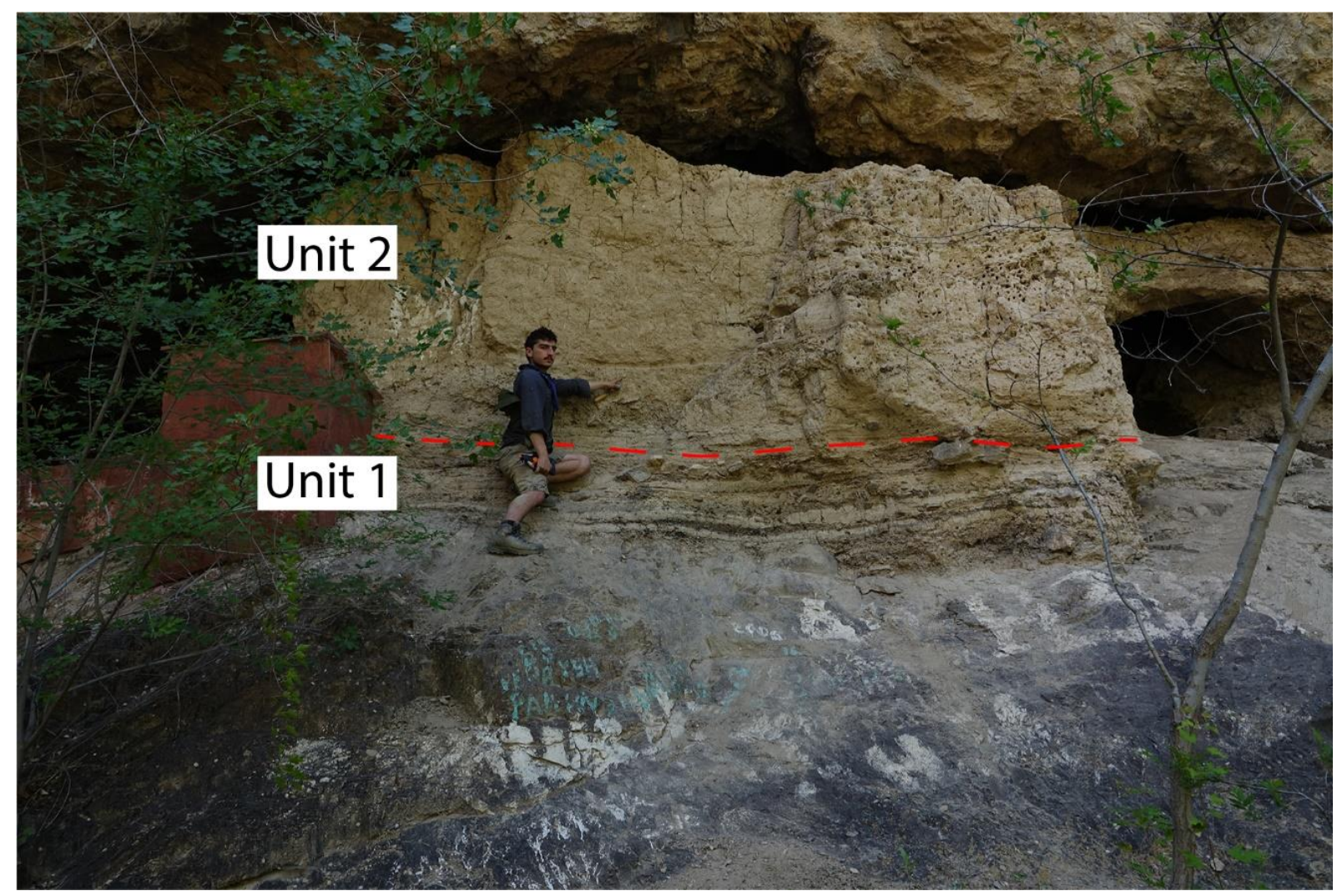

Figure. 2. The best-preserved sediment column from the Nazugum rockshelter. Dashed line marks the boundary between the two broad stratigraphic units; Unit 1: fluvial sediments. Unit 2: aeolian loess sediments. Notice sediment arch intersecting with the stratigraphy at the right extent of the figure.

\section{Archaeological assemblage}

Due to the religious use and frequent pilgrim visits to the rockshelter, we did not carry out test excavations. Our work at the rockshelter focused on documenting the preserved stratigraphy and collecting geological samples of bedrock and possible lithic raw materials.

During the close observations of the sediment column, a total of 7 lithic artefacts were recovered from the profile and illustrated in Fig. 3. Fragments of animal bones and remnants of charcoal were found in association with lithic artefacts and sampled for radiocarbon dating. All these materials were collected from the same level indicating an occupational horizon. The artefacts were found in the massive loess unit indicating that they were deposited by humans during concurrent loess deposition and thus were not heavily reworked by the channel activity that formed the lower fluvial layers. However, due to the proximity of the cave to the river, we cannot exclude the possibility that both the loess and the artifacts could have been influenced by fluvial action, most probably during flood events. In Kazakhstan, aqueous induced 
reworking of loess in a cave/rockshelter context has also been reported in the site of Jetiotau (Varis et al., 2022).

A small number of archaeological lithics $(n=7)$ was sticking out of the sediment column and collected by our team. The majority of the lithics are bladelets $(n=5)$, the remaining two are flakes knapped on various silica rocks (Namen et al., 2020b). All the lithics contain thick layers of calcareous concretions, and some of them are entirely covered by it. The small number of lithics hinders assigning the site within a specific cultural-chronological tradition, but their techno-typological attributes give an insight into the reduction techniques. Although it is difficult to explicitly determine the knapping method, we note the production of bladelets and small flakes (Figure 2). In spite of the absence of cores, we assume that the recovered bladelets were produced from prismatic and/or platform cores. The Holocene character of the assemblage is determined by radiocarbon date from the charcoal sample that yielded a calibrated age (2sigma) of 2470-2288 cal BC (Table 1). Thus, the occupational horizon of the Nazugum rockshelter falls within the frame of a late Eneolithic and early Bronze Age periods.

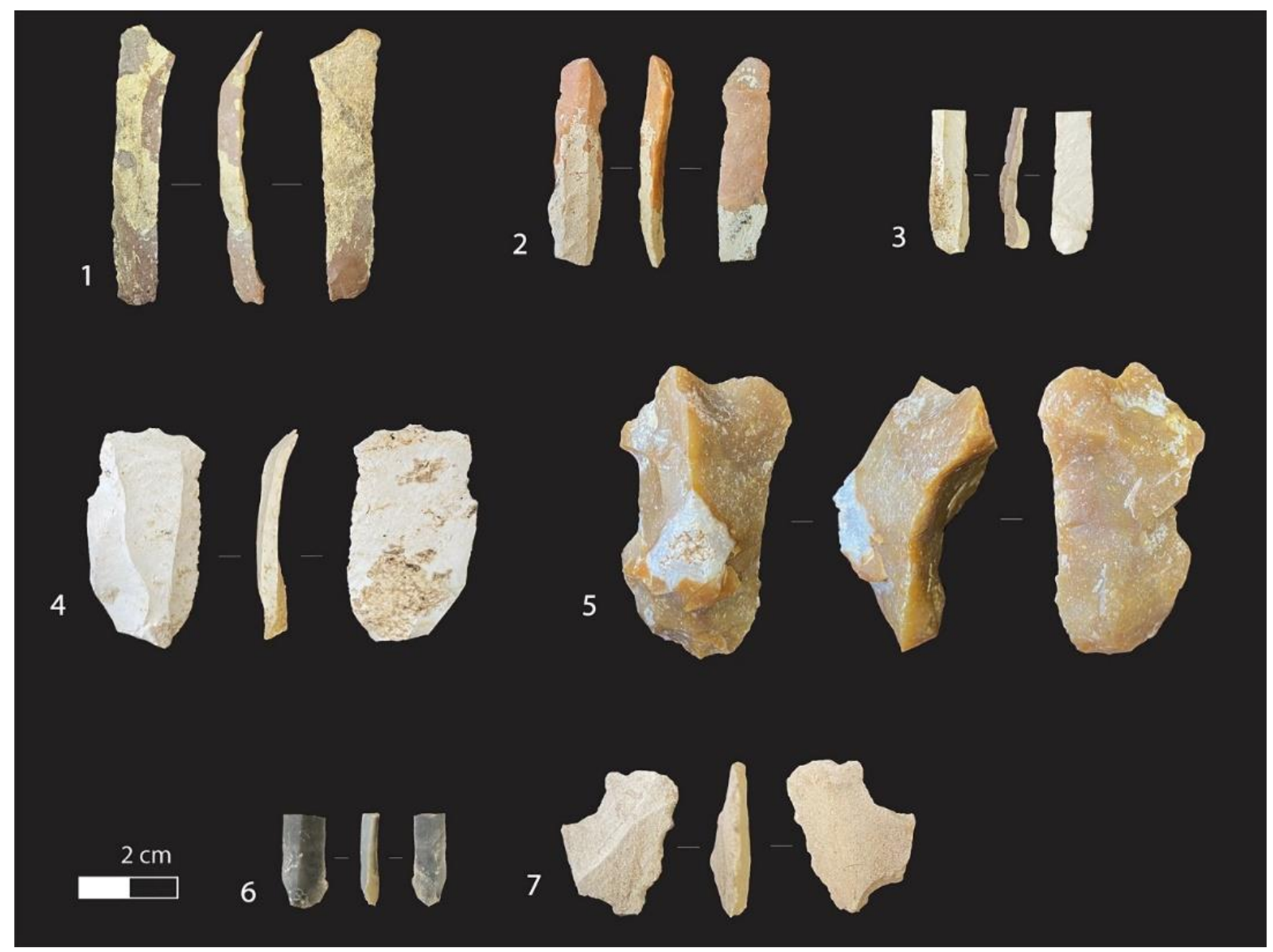

Figure 3. Lithic assemblage retrieved from the sediment column of the Nazugum rockshelter. 1-4, 6 - bladelets and bladelet fragments. 5,7 - flakes.

Table 1. Radiocarbon date for Nazugum rockshelter. Age calibration was performed using the IntCal20 dataset (Reimer et al., 2020)and calibration software OxCal 4.4.4 (Bronk Ramsey, 2021).

\begin{tabular}{lllllll}
\hline Lab & $\begin{array}{l}{ }^{14} \mathbf{C} \text { Age } \\
{[\mathbf{y r} \text { BP] }}\end{array}$ & $\begin{array}{l}\boldsymbol{\delta 1 3 C} \\
\text { AMS [\%o] }\end{array}$ & Cal 1-sigma & Cal 2-sigma & $\begin{array}{l}\text { C } \\
{[\%]}\end{array}$ & $\begin{array}{l}\text { Material } \\
\text { dated }\end{array}$ \\
\hline MAMS-43624 & $3897 \pm 31$ & $-25,4$ & cal BC 2460-2344 & cal BC 2470-2288 & 59,8 & charcoal \\
\hline
\end{tabular}




\section{Discussion and conclusions}

Systematic cave survey provides promising results for the discovery of new sites with Holocene materials in Kazakhstan. In the case of Nazugum rockshelter, the lack of excavations hinders a clear interpretation of site use. Even though a small number of lithics was sticking out of the profile, the presence of bones and charcoal could indicate that archaeological features and structures may still be preserved in the interior of the rockshelter. If we also account for the intense erosion, we hypothesize that the volume of the archaeological material deposited in Nazugum rockshelter is much greater than what we retrieved from the profile. In this context, it is important to note that the lithics are found near the bottom of the loess unit, suggesting that human groups visited the rockshelter soon after the fluvial action that deposited the channel deposits of Unit 1 ceased and the rockshelter become accessible.

The site of Nazugum has also important implications for the formation and preservation of cave and rockshelter archaeological sites in Kazakhstan. First, the presence of a thick loess deposit that fills the majority of the rockshelter demonstrates the influence of loess-deposition for the build-up of thick archaeological sequences in Kazakhstan, as well as the potential masking of archaeological sites from the landscape (see also discussion in Varis et al., 2022). In the case of Nazugum, the radiocarbon sample located close to the base of the loess unit provides a terminus post-quem for the onset of loess deposition when assuming that the charcoal is preserved in situ. Therefore, based on this correlation we can infer about 2 meters of loess deposition in the proximity of the rockshelter for the last 4,500 years. In Kazakhstan, loess deposition is mostly associated with the cold and dry conditions that characterize the Pleistocene, while Holocene is more likely associated with pedogenesis rather than aeolian sedimentation (Fitzsimmons et al., 2018). However, since loess accumulation is driven by both climate fluctuations and topography (Sprafke et al., 2018), local variations in loess distribution might be expected. In the case of the Ili basin, where Nazugum rockshelter is located, Li et al. (2018) demonstrated that loess is locally derived. This result is especially important for the formation and visibility of archaeological sites in intermontane valleys like the Ili, because it highlights that local piedmont processes can produce thick loess deposits even in areas away from deserts.

In the context of site formation, even though aqueous processes have usually minor impact in the formation and reworking of sediments in the semi-arid landscape of Kazakhstan (Varis et al., 2022), we see that in the case of Nazugum rockshelter they play a prominent role in the preservation of the archaeological record through time.

Finally, before any destructive work is to take place, we consider it of utmost importance to conduct work in collaboration with the Kazakh and Uyghur communities of Almaty region, so the significance of the monument as both a prehistoric and contemporary landmark can be preserved. Future work in Nazugum rockshelter will focus on the detailed recording of the exposed archaeological record. This endeavour is critical since the highly erosional water channels will eventually remove completely the remaining archaeological deposits. More specialized geoarchaeological analysis will shed light on the formation processes that shaped the archaeological assemblage, the loess deposits, and the morphology of the rockshelter through time. 


\section{Acknowledgements}

We would like to thank Dean Mendigul Nogaibaeva, Prof. Gani Omarov and Dr. Rinat Zhumatayev (Al-Farabi Kazakh National University) for their support. The study was performed within the PALAEOSILKROAD project, and all field research was conducted under license $\mathrm{n}^{\circ} 15008746$ (12.05.2015) of the National Museum of the Republic of Kazakhstan based on the collaboration protocol between the University of Tübingen and the National Museum. This project has received funding from the European Research Council (ERC) under the European Union's Horizon 2020 research and innovation programme (grant agreement $\mathrm{n}^{\circ}$ 714842; PALAEOSILKROAD project). We would also like to thank the two anonymous reviewers who helped to substantially improve the manuscript.

\section{References}

Baytanaev, B.A., Goryachev, A.A., Egorova, T.A., Ergeshbaev, A.A., Baytanaeva, A.B., Baytanaev, E.B., 2018. Arkheologicheskie issledovaniya v peschere Tuttybulaq-1 v 2018 g. [Archaeological research in Tuttybulaq-1 cave in 2018]. Arkheologiya Kazakhstana 1-2, 272-285.

Bronk Ramsey, C., 2021. OxCal v4.4.4 [WWW Document]. URL https://c14.arch.ox.ac.uk/oxcal.html (accessed 12.26.21).

Cuthbertson, P., Ullmann, T., Büdel, C., Varis, A., Namen, A., Seltmann, R., Reed, D., Taimagambetov, Z., Iovita, R., 2021. Finding karstic caves and rockshelters in the Inner Asian mountain corridor using predictive modelling and field survey. PLOS ONE 16, e0245170. doi:10.1371/journal.pone.0245170

Fitzsimmons, K.E., Sprafke, T., Zielhofer, C., Günter, C., Deom, J.-M., Sala, R., Iovita, R., 2018. Loess accumulation in the Tian Shan piedmont: Implications for palaeoenvironmental change in arid Central Asia. Quaternary International 30-43. doi:10.1016/j.quaint.2016.07.041

Frachetti, M.D., 2012. Multiregional Emergence of Mobile Pastoralism and Nonuniform Institutional Complexity across Eurasia. Current Anthropology 53, 2-38. doi:10.1086/663692

Frachetti, M.D., Mar'yashev, A.N., 2007. Long-Term Occupation and Seasonal Settlement of Eastern Eurasian Pastoralists at Begash, Kazakhstan. Journal of Field Archaeology 32, 221-242. doi:10.1179/009346907791071520

Frachetti, M.D., Benecke, N., Mar’yashev, A.N., Doumani, P.N., 2010. Eurasian pastoralists and their shifting regional interactions at the steppe margin: settlement history at Mukri, Kazakhstan. World Archaeology 42, 622-646. doi:10.1080/00438240903371270

Iovita, R., Varis, A., Namen, A., Cuthbertson, P., Taimagambetov, Z., Miller, C.E., 2020. In search of a Paleolithic Silk Road in Kazakhstan. Quaternary International. doi:10.1016/j.quaint.2020.02.023

Li, Y., Song, Y., Fitzsimmons, K.E., Chen, X., Wang, Q., Sun, H., Zhang, Z., 2018. New evidence for the provenance and formation of loess deposits in the Ili River Basin, Arid Central Asia. Aeolian Research 35, 1-8. doi:10.1016/j.aeolia.2018.08.002

Namen, A., Aristeidis, V., Cuthbertson, P., Iovita, R., Taimagambetov, Z., 2020a. Predvaritel'nye itogi razvedovatel'nykh rabot proekta PALAEOSILKROAD: mul'tidistsiplinarnyi podkhod v issledovaniyakh [Preliminary survey resuts of the PALAEOSILKROAD project: multidisciplinary approach]. In: Proceedings of the International scientific and practical conference "Great Steppe in light of archaeological and interdisciplinary research." Presented at the Margulan Readins - 2020, A. Kh. Margulan Institute of Archaeology, Almaty, pp. 60-69.

Namen, A., Cuthbertson, P., Varis, A., Schmidt, P., Taimagambetov, Z., Iovita, R., 2020b. Preliminary results of the first lithic raw material survey in the piedmont zones of Kazakhstan. SocArXiv. doi:10.31235/osf.io/uztq6

Outram, A.K., Stear, N.A., Bendrey, R., Olsen, S., Kasparov, A., Zaibert, V., Thorpe, N., Evershed, R.P., 2009. The Earliest Horse Harnessing and Milking. Science 323, 1332-1335. doi:10.1126/science.1168594

Reimer, P.J., Austin, W.E.N., Bard, E., Bayliss, A., Blackwell, P.G., Ramsey, C.B., Butzin, M., Cheng, H., Edwards, R.L., Friedrich, M., Grootes, P.M., Guilderson, T.P., Hajdas, I., Heaton, T.J., Hogg, A.G., Hughen, K.A., Kromer, B., Manning, S.W., Muscheler, R., Palmer, J.G., Pearson, C., Plicht, J. van der, Reimer, R.W., Richards, D.A., Scott, E.M., Southon, J.R., Turney, C.S.M., Wacker, L., Adolphi, F., Büntgen, U., Capano, M., Fahrni, S.M., Fogtmann-Schulz, A., Friedrich, R., Köhler, P., Kudsk, S., Miyake, F., Olsen, J., Reinig, F., Sakamoto, M., Sookdeo, A., Talamo, S., 2020. The IntCal20 Northern Hemisphere Radiocarbon Age Calibration Curve (0-55 cal kBP). Radiocarbon 62, 725-757. doi:10.1017/RDC.2020.41 
Sprafke, T., Fitzsimmons, K.E., Grützner, C., Elliot, A., Marquer, L., Nigmatova, S., 2018. Reevaluation of Late Pleistocene loess profiles at Remizovka (Kazakhstan) indicates the significance of topography in evaluating terrestrial paleoclimate records. Quaternary Research 1-17. doi:10.1017/qua.2017.103

Taimagambetov, Zh., Nokhrina, T.I., 1998. Arheologicheskie kompleksy peshchery Karaungur (Yuzhnyi Kazahstan) [Archaeological complexes from Karaungur Cave (South Kazakhstan)]. Miras, Turkestan.

Varis, A., Miller, C., Cuthbertson, P., Namen, A., Taimagambetov, Z., Iovita, R., 2021. The Effect of Formation Processes on The Frequency of Palaeolithic Cave Sites in Semi-Arid Zones: Insights From Kazakhstan.

Zaibert, V., 1993. Eneolit Uralo-Irtyshskogo mezdurech'ya [Eneolithic of the Ural and Irtysh interfluve]. Margulan Institute of Archaeology, Academy of Sciences of the Republic of Kazakhstan, Petropavlovsk.

Zheleznyakov, B., Sapatayev, S., Biver, J., 2020. Tamgaly (Kazakhstan), Petroglyphs within the Landscape. In: Encyclopedia of Global Archaeology. Springer International Publishing, Cham, pp. 1-6. doi:10.1007/978-3-319-51726-1_2832-1 